\title{
Antitumor activity of Chlorella sorokiniana and Scenedesmus sp. microalgae native of Nuevo León State, México
}

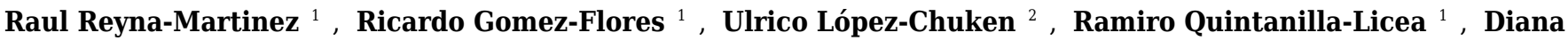 \\ Caballero-Hernandez ${ }^{1}$ ， Cristina Rodríguez-Padilla ${ }^{1}$, Julio Cesar Beltrán-Rocha ${ }^{2}$, Patricia Tamez-Guerra ${ }^{\text {Corresp. }}{ }^{1}$ \\ 1 Facultad de Ciencias Biológicas, Universidad Autónoma de Nuevo León, San Nicolas de los Garza, Nuevo Leon, Mexico \\ 2 Facultad de Ciencias Químicas, Universidad Autónoma de Nuevo León, San Nicolas de los Garza, Nuevo Leon, Mexico \\ Corresponding Author: Patricia Tamez-Guerra \\ Email address: patricia.tamezgr@uanl.edu.mx
}

Cancer cases result in $13 \%$ of all deaths worldwide. Unwanted side effects in patients under conventional treatments have led to the search for beneficial alternative therapies. Microalgae synthesize compounds with known in vitro and in vivo biological activity against different tumor cell lines. Therefore, native microalgae from the State of Nuevo Leon, Mexico may become a potential source of antitumor agents. The aim of the present study was to evaluate the in vitro cytotoxic effect of Nuevo Leon regional Chlorella sorokiniana (Chlorellales: Chlorellaceae) and Scenedesmus sp. (Chlorococcales: Scenedesmaceae). Native microalgae crude organic extracts cytotoxicity against murine L5178Y-R lymphoma cell line and normal lymphocyte proliferation were evaluated using the MTT reduction colorimetric assay. Cell death mechanism was analyzed by acridine orange and ethidium bromide staining, DNA degradation in $2 \%$ agarose gel electrophoresis and caspases activity. Results indicated significant $(p<0.05) 61.89 \% \pm 3.26 \%$ and $74.77 \%$ $\pm 1.84 \%$ tumor cytotoxicity by $C$. sorokiniana and Scenedesmus sp. methanol extracts, respectively, at $500 \mu \mathrm{g} / \mathrm{mL}$, by the mechanism of apoptosis. This study contributes to Mexican microalgae biodiversity knowledge and their potential as antitumor agent sources. 
1 For: PeerJ as original research paper

2 Antitumor activity of Chlorella sorokiniana and Scenedesmus sp. microalgae native of

4 Raul Reyna-Martinez ${ }^{\mathrm{a}}$, Ricardo Gomez-Flores ${ }^{\mathrm{a}}$, Ulrico López-Chuken ${ }^{\mathrm{b}}$, Ramiro Quintanilla$5 \quad$ Licea $^{\mathrm{a}}$, Diana Caballero-Hernandez ${ }^{\mathrm{a}}$, Cristina Rodríguez-Padilla ${ }^{\mathrm{a}}$, Julio C. Beltrán-Rocha ${ }^{\mathrm{b}}$, and Patricia Tamez-Guerra ${ }^{a *}$.

7 anniversidad Autónoma de Nuevo León (UANL), Facultad de Ciencias Biológicas (FCB). Email: RRM: raul.reyna.martinez20@gmail.com Orcid ID: 0000-0001-6909-6459; RGF: rgomez60@hotmail.com Orcid ID: 0000-0002-9518-4433; Email: ramiro.quintanillalc@uanl.edu.mx Orcid ID: 0000-0002-4379-6913; DCH:

11 diana.caballerohr@uanl.edu.mx Orcid ID: 0000-0002-5446-1238; CRP: crrodrig07@gmail.com

12 Orcid ID: 0000-0001-5469-8449; PTG: patamez@hotmail.com, Orcid ID: 0000-0002-4831-2340

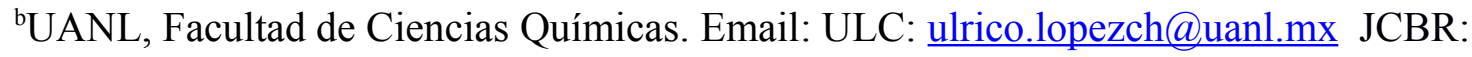

*Corresponding author; E-mail: patamez@,hotmail.com, patricia.tamezgr@uanl.edu.mx

16 Short title: Antitumor activity of two microalgae 


\section{Abstract.}

18 Cancer cases result in $13 \%$ of all deaths worldwide. Unwanted side effects in patients under conventional treatments have led to the search for beneficial alternative therapies. Microalgae synthesize compounds with known in vitro and in vivo biological activity against different tumor cell lines. Therefore, native microalgae from the State of Nuevo Leon, Mexico may become a potential source of antitumor agents. The aim of the present study was to evaluate the in vitro cytotoxic effect of Nuevo Leon regional Chlorella sorokiniana (Chlorellales: Chlorellaceae) and

24 Scenedesmus sp. (Chlorococcales: Scenedesmaceae). Native microalgae crude organic extracts 25 cytotoxicity against murine L5178Y-R lymphoma cell line and normal lymphocyte proliferation

26 were evaluated using the MTT reduction colorimetric assay. Cell death mechanism was analyzed

27 by acridine orange and ethidium bromide staining DNA, degradation in $2 \%$ agarose gel

28 electrophoresis and caspases activity.

29 Results indicated significant $(p<0.05) 61.89 \% \pm 3.26 \%$ and $74.77 \% \pm 1.84 \%$ tumor cytotoxicity by $C$. sorokiniana and Scenedesmus sp. methanol extracts, respectively, at $500 \mu \mathrm{g} / \mathrm{mL}$, by the mechanism of apoptosis. This study contributes to Mexican microalgae biodiversity knowledge and their potential as antitumor agent sources. 
Most commercialized drugs are synthetic derivatives from natural products, or are the result of the systematic screening of terrestrial organisms, such as plants or microorganisms.

Analysis of molecules produced by aquatic organisms has shown that microalgae synthesize a large number of bioactive compounds, including pigments, sterols, polyphenols, fatty acids, proteins, vitamins, alkaloids, and sulfated polysaccharides. This group of microorganisms is extremely diverse and represents a number of unexploited natural sources for bioactive agents. Furthermore, the microalgae intake of polluting elements such as nitrogen, phosphorus, and sulphur for their own growing can be considered an advantage, since such elements can be also metabolized by harmful aquatic weeds to proliferate.

Microalgae are unicellular, simple, primitive, and photosynthetic organisms, producing bioactive compounds for pharmaceutical and biotechnological applications (Shanab et al. 2012, El Baky, El-Baroty \& Ibrahim 2014, Shalaby 2011), which have shown antiviral, antimicrobial, immunomodulatory, and antitumor properties (Lordan, Ross \& Stanton 2011, Teas \& Irhimeh 2012). beneficial alternative therapeutic agents (Rengarajan et al. 2013). Antitumor activity of microalgal compounds can be explained by their ability to cross the lipophilic membranes and interact with proteins involved in apoptosis. In addition, several microalgal compounds induce DNA-dependent DNA polymerases inhibition, cyclins expression alteration, or major transduction pathways interference. Microalgal compounds have been related to immune response stimulation (Baudelet et al. 2013), as well as cytotoxic against several cancer cell lines

55 (Shanab et al. 2012, Lin et al. 2017). If any compound shows cytotoxic activity against cancer 
57 and if its cellular toxicity mechanism is via necrosis or apoptosis. Both apoptosis and necrosis

58 can occur independently, sequentially and/or simultaneously, where the stimuli degree and/or

59 type determines either apoptotic or necrotic death cell (Elmore 2007). In some cases, cancer

60 chemotherapy treatments result in DNA damage, leading to apoptotic cell death (Elmore 2007).

61 Apoptosis involves DNA damage and caspases activation. Chlorella spp. extracts have resulted

62 in cell death via DNA damage (Yusof et al. 2010) and caspases activation, demonstrating the

63 apoptosis pathway (Lin et al. 2017).

64 The aim of the present study was to evaluate the potential of Nuevo Leon, Mexico native

65 microalgae, C. sorokiniana and Scenedesmus sp. extracts, isolated from Nuevo Leon, Mexico,

66 against murine L5178Y-R lymphoma cells. To our knowledge, this is the first report of antitumor

67 activity of microalgae isolated from this geographical area.

MATERIALS AND METHODS

Reagents, culture media, and tumor cells.

L-glutamine and penicillin-streptomycin solutions were purchased from Life Technologies

71 (Grand Island, NY). Concanavalin A (Con A), RPMI 1640 medium, fetal bovine serum (FBS), sodium dodecyl sulfate (SDS), $N, N$-dimethylformamide (DMF), phosphate buffered saline (PBS), and 3-[4,5-dimethylthiazol-2-yl]-2,5-diphenyltetrazolium bromide (MTT) were obtained from Sigma-Aldrich (St. Louis, MO). Vincristine was obtained from Vintec (Columbia, S.A. de C.V., Ciudad de México). Extraction buffer was prepared by dissolving 20\% (wt/vol) SDS at $37^{\circ} \mathrm{C}$ in a solution of $50 \%$ each DMF and demineralized water, and the $\mathrm{pH}$ was adjusted to 4.7. The tumor cell line L5178Y-R (mouse DBA/2 lymphoma) was purchased from the American

78 Type Culture Collection (LY-R, ATCC ${ }^{\circledR}$ CRL-1722 ${ }^{\mathrm{TM}}$, Rockville, MD), maintained in culture 
80 penicillin-streptomycin solution (referred as complete RPMI medium) at $37^{\circ} \mathrm{C}$, in a humidified

81 atmosphere of $5 \% \mathrm{CO}_{2}$ in air. Cellular density was kept between $10^{5}$ and $10^{6} \mathrm{cells} / \mathrm{mL}$.

\section{Microalgae strains and culture.}

83 C. sorokiniana was isolated from San Juan River in the municipality of Cadereyta

$84\left(\underline{\left.26^{\circ} 21^{\prime} 55^{\prime \prime} \mathrm{N} 98^{\circ} 51^{\prime} 15^{\prime \prime} \mathrm{O}\right)}\right)$, whereas Scenedesmus was obtained from Pesquería River in the

85 municipality of Apodaca $\left(\underline{\left.25^{\circ} 47^{\prime} 06^{\prime \prime} \mathrm{N} 100^{\circ} 03^{\prime} 04^{\prime \prime} \mathrm{O}\right)}\right.$ Nuevo Leon, Mexico. C. sorokiniana

86 molecular identification using the P2F (5'-GGC TCA TTA AAT CAG TTA TAG-3') and P2R (5'-

87 CCT TGT TAC GA(C/T) TTC TCC TTC-3') primers (Lee \& Hur 2009), which amplifies for a

881700 bp fragment of the 18S gene, as previously reported by Cantú-Bernal (2017). Amplification

89 conditions were an initial denaturation cycle at $95^{\circ} \mathrm{C}$ for $5 \mathrm{~min}, 30-35$ denaturation cycles at $95^{\circ} \mathrm{C}$

90 for $30 \mathrm{sec}$, alignment at $50-55^{\circ} \mathrm{C}$ for $30 \mathrm{sec}$, and an extension process at $72^{\circ} \mathrm{C}$ for $105 \mathrm{sec}$,

91 followed by a final extension at $72^{\circ} \mathrm{C}$ for $7 \mathrm{~min}$. The PCR product was confirmed by

92 electrophoresis on $1.5 \%$ agarose gel at 100 Volts for $35 \mathrm{~min}$, were the expected $1700 \mathrm{bp}$ band was

93 observed. Once the PCR product was confirmed, the band was purified, for which the Wizard SV

94 Gel and PCR clean-up system kit (Promega, Invitrogen) was used. For the band sequencing, the

95 product was sent to the synthesis and sequencing unit of the Institute of Biotechnology,

96 Universidad Nacional Autónoma de México. The edition and analysis of the Chlorella sp.

97 sequence similarity percentage was carried out using the program Bioedit Sequence Alignment

98 Editor v. 7.1 .9 by sequence identity matrix means, after being compared with sequences reported

99 in the GenBank.

100 For microalgae culture, water samples were taken on $50 \mathrm{~mL}$ sterile Falcon tubes and kept

101 at $5^{\circ} \mathrm{C} \pm 2^{\circ} \mathrm{C}$ on ice. Then, $5 \mathrm{~mL}$ were transferred to $250 \mathrm{~mL}$ Erlenmeyer flasks, containing 100

$102 \mathrm{~mL}$ of LC culture medium, as developed and reported by López-Chuken, Young \& Guzman-Mar

103 (2010). Flasks were then incubated at room temperature $\left(25^{\circ} \mathrm{C} \pm 3^{\circ} \mathrm{C}\right)$ in a continuous shaker at 
$104120 \mathrm{x}$ g and under light radiation using 100 Watt white fluorescent light bulb as a continuous

105 artificial light source (1000 lux approximately). Flasks were incubated for $14 \mathrm{~d}$ until green

106 growth was observed, after which, $100 \mu \mathrm{L}$ were transferred to Petri dishes containing the same

107 culture medium, but solidified with $1.5 \%$ of bacteriological agar. Inoculated dishes were

108 incubated at $30^{\circ} \mathrm{C} \pm 2^{\circ} \mathrm{C}$ by using a 100 watt white fluorescent light bulb as a continuous

109 artificial light until isolated green colonies were observed. Single colonies were collected using a

110 bacteriological loop and placed in Erlenmeyer flasks containing $100 \mathrm{~mL}$ of algal LC liquid

111 culture medium. Next, flasks were incubated under the same conditions described above. This

112 process allowed us selecting a single microalgae genus by picking up a single colony; however,

113 given that microalgae tend to grow in consortia with bacteria and yeasts, microalgal cultures were

114 treated with an antibiotic and antimycotic solution containing $500 \mathrm{UI} / \mathrm{mL}$ penicillin, $500 \mu \mathrm{g} / \mathrm{mL}$

115 streptomycin, $50 \mu \mathrm{g} / \mathrm{mL}$ gentamicin, and $1.25 \mu \mathrm{g} / \mathrm{mL}$ fungizone. For this, $5 \mathrm{~mL}$ of LC liquid

116 culture medium with antibiotics were placed in $15 \mathrm{~mL}$ conical tubes, after which $0.25 \mathrm{~mL}$ of the

117 algal culture were added and tubes were incubated for $48 \mathrm{~h}$, under same shaking and lighting

118 conditions described above. After the incubation period, $500 \mu \mathrm{L}$ of the cultures were transferred

119 into $50 \mathrm{~mL}$ of sterilized LC liquid culture medium without antibiotics producing axenic cultures

120 of C. sorokiniana and Scenedesmus sp. isolates. Each axenic culture was grown for $14 \mathrm{~d}$ in $1-\mathrm{L}$

121 Erlenmeyer flasks containing $500 \mathrm{~mL}$ of LC liquid culture medium, until exponential growth

122 phase was reached (based on growth curve, supplemental Fig. S1). Next, each complete culture

123 was transferred to individual bioreactor tanks containing $14.5 \mathrm{~L}$ of LC culture medium.

124 Photobioreactor tanks were designed by López-Chuken work team, and consisted of circular

125 acrylic tanks of $30 \mathrm{~cm}$ of diameter and height; aeration was supplemented by air pumps with an

126 adapted $0.2 \mu \mathrm{m}$ filter at $1-\mathrm{L} / \mathrm{min}$ flow rate, radiated by continuous artificial LED white lights at

1271500 lux of intensity, and agitation by rotary plastic pallets at $50 \mathrm{rpm}$ (supplementary material

128 Fig. S2). Biomass production in bioreactors was monitored every $2 \mathrm{~d}$ (Tuesdays, Thursdays, and 
129 Saturdays) by taking a $10 \mathrm{~mL}$ sample with a sterile pipette and filtering through a previously

130 weighed $0.7 \mu \mathrm{m}$-pore size microfiber paper. Then the paper was dried at $70^{\circ} \mathrm{C}$ inside an oven and

131 weighed again; this monitoring process was repeated until the biomass production showed no

132 increase. Once the maximum biomass production was reached, bioreactor tanks were stored at

$1334^{\circ} \mathrm{C} \pm 2{ }^{\circ} \mathrm{C}$, until most microalgae biomass precipitated, then, the supernatant was decanted

134 (supplementary material Fig. S3). The collected wet biomass was the centrifuged at $9000 \mathrm{rpm}$ for

$13510 \mathrm{~min}$ (ST16R model, Thermo Fisher Scientific, Waltham MA) and frozen dried (Labconco,

136 Kansas City, MO).

137 Biomass dried samples of $C$. sorokiniana and Scenedesmus sp. were placed in separate Whatman 138 cellulose extraction thimbles $(33 \times 80 \mathrm{~mm}$, thickness $1.5 \mathrm{~mm})($ Sigma-Aldrich $)$ and placed in a

139 Soxhlet extraction apparatus (Reyna-Martinez et al. 2014), which is a continuous system

140 consisting of a flat bottomed round flask, an extraction chamber with a siphon, and a condenser.

141 This method was selected since this extraction is very practical and recommended by most of the

142 methanol-soluble compounds for biological material recovering. A round flask filled with 600

$143 \mathrm{~mL}$ of methanol was used and the extraction lasted $48 \mathrm{~h}$ for each microalgae. Methanol was

144 selected based on preliminary results where methanol extracts showed the highest cytotoxic

145 activity against L5178Y-R cell line; whereas chloroformic extracts did not show cytotoxic effects

146 and hexane itself showed cytotoxicity against the tumor cell line tested. After the biological

147 material compounds were extracted with methanol, the solutions were filtered using Whatman

148 filter paper, and solvent was evaporated using a rotary evaporator, leaving approximately 10 to 15

$149 \mathrm{~mL}$ of liquid material. Remaining solvent was further removed by a vacuum desiccator. Extracts

150 were dissolved in RPMI medium at a concentration of $1 \mathrm{mg} / \mathrm{mL}$ and kept frozen until use. From

151 this stock, serial 1:1 dilutions from 500 to $7.8 \mu \mathrm{g} / \mathrm{mL}$ were prepared. 
152 The tumor cell line L5178Y-R (mouse DBA/2 lymphoma) was purchased from the American

153 Type Culture Collection (LY-R, ATCC $^{\circledR}$ CRL-1722 ${ }^{\mathrm{TM}}$, Rockville, MD), maintained in culture

154 flasks with RPMI 1640 medium supplemented with 10\% FBS, 1\% L-glutamine, and 0.5\%

155 penicillin-streptomycin solution (referred as complete RPMI medium) at $37^{\circ} \mathrm{C}$, in a humidified

156 atmosphere of $5 \% \mathrm{CO}_{2}$ in air. Cellular density was kept between $10^{5}$ and $10^{6} \mathrm{cells} / \mathrm{mL}$.

\section{Tumor cytotoxicity and apoptosis assays.}

158 To determine the cytotoxic effect of C. sorokiniana and Scenedesmus sp. methanol extracts

159 against L5178Y-R tumor cells, cell cultures were collected and washed three times in RPMI 160 medium, then suspended and adjusted to $5 \times 10^{4}$ cells $/ \mathrm{mL}$ with complete RPMI medium. One

161 hundred microliters of the cell suspensions were then added to flat-bottomed 96-well plates

162 (Becton Dickinson, Cockeysville, MD), containing $100 \mu \mathrm{L}$ of complete RPMI, methanol

163 microalgae extracts at various concentrations, vincristine $(250 \mu \mathrm{g} / \mathrm{mL})$ as positive control, and

164 RPMI medium as negative control; all treatments were tested in triplicate. Microplates were

165 incubated for $48 \mathrm{~h}$ at $37^{\circ} \mathrm{C}$ with $5 \% \mathrm{CO}_{2}$, then $15 \mu \mathrm{L}$ of MTT were added $(0.5 \mu \mathrm{g} / \mathrm{mL}$, final

166 concentration), and cultures were incubated for 3 additional hours. After this, supernatant was

167 removed and $80 \mu \mathrm{L}$ of DMSO were added to all wells. Optical densities, resulting from dissolved

168 formazan crystals, were then read in a microplate reader (DTX 880 Multimode detector, Becton

169 Dickinson, Austria) at $570 \mathrm{~nm}$ (Gomez-Flores et al. 2009). The percentage of cytotoxicity was

170 calculated as follows:

$171 \%$ Cytotoxicity $=100-\left[\left(\mathrm{A}_{570}\right.\right.$ in extract-treated cells $/ \mathrm{A}_{570}$ in untreated cells $\left.) \mathrm{X} 100\right]$.

172 Apoptosis induction by $C$. sorokiniana and Scenedesmus sp. methanol extracts against L5178Y-R

173 cell line was evaluated in vitro by acridine orange and ethidium bromide staining. For this, $1 \times 10^{6}$ 
174 L5178Y-R tumor cells were placed in 24-well plates in the presence of $500 \mu \mathrm{g} / \mathrm{mL}$ methanol

175 extracts, and incubated for $24 \mathrm{~h}$. Then, $500 \mu \mathrm{L}$ of RPMI, plus $1-\mu \mathrm{L}$ of acridine orange and 100

$176 \mu \mathrm{g} / \mathrm{mL}$ ethidium bromide (1:1 ratio) were added to the wells. Next, cultured cells were incubated

177 for $5 \mathrm{~min}$, washed with 1-mL PBS, and suspended in $100 \mu \mathrm{L}$ of RPMI medium; after incubation

178 period, $10 \mu \mathrm{L}$ of cell suspension were placed between a slide and a coverslip for fluorescence

179 microscope visualization (Inverted Tissue Culture Fluorescence Microscope Olympus IX-70,

180 Representaciones y Distribuciones FAL, S.A. de C.V., Naucalpan, Estado de México).

181 Acridine orange stains viable cells and dead cells (green cells), whereas ethidium bromide only

182 stains those cells that have lost the integrity of their membrane (orange cells). Therefore, viable

183 cells appear in a uniform green tone, cells found in apoptosis appear in a spotty green or granular

184 in the center due to the condensation of chromatin and fragmentation of the nucleus, whereas

185 cells in necrosis appear in a uniform orange hue (Coligan et al. 1995).

186 In addition, apoptosis induction was evaluated by DNA degradation (Orozco-Flores et al. 2017).

187 For this, cells were incubated for $48 \mathrm{~h}$ with C. sorokiniana and Scenedesmus sp. methanol

188 extracts at $500 \mu \mathrm{g} / \mathrm{mL}$, testing their respective negative (culture medium) and positive $(20 \mu \mathrm{g} / \mathrm{mL}$

189 Actinomycin D) controls. After the incubation period, cells were collected and centrifuged at

$1902000 \mathrm{rpm}$ for $10 \mathrm{~min}$, then washed with PBS and extracted using the AxyPrep Multisource

191 Genomic DNA Miniprep Kit (Axygen, MA). In order to visualize the extracted DNA, the sample

192 was separated by 2\% agarose gel electrophoresis, using SB buffer for the electrophoretic shift at

$193 \mathrm{70V}$ for $20 \mathrm{~min}$ and $110 \mathrm{~V}$ for $1 \mathrm{~h}$. After this, gel was stained with $5 \mathrm{ng} / \mathrm{mL}$ ethidium bromide and

194 photographs were documented under High Performance Ultraviolet Transilluminator (UVP, LLC,

195 Upland, CA) light. DNA like-ladder fragmentation indicates apoptotic activity, whereas DNA

196 smear represents cell death by necrosis.

197 In early apoptosis stages caspase enzymes are activated. Caspase participate in the cleavage of

198 protein substrates leading to cell disassembly. Cleavage of protein substrates leads to a 
199 fluorescent monoamide formation and finally to a rhodamine 110 conversion. For apoptotic

200 pathway involving caspases, caspase can be monitored by measuring fluorescence intensity using 201 microplate wells (Towhid et al. 2013). For this, L5178Y-R cells ( 5 X10 $0^{5}$ cells/well) were seeded

202 in a 48 wells plate, and treated with actinomycin D $(800 \mathrm{ng} / \mathrm{mL})$ as positive control, or Chlorella 203 and Scenedesmus methanolic extracts at $500 \mu \mathrm{g} / \mathrm{mL}$. Cultures were then incubated for $24 \mathrm{~h}$ at $37^{\circ}$

204 C, after which, activated caspases were detected with the CaspGLOW ${ }^{\mathrm{TM}}$ red active caspase 205 staining kit following manufacturer's instructions. Fluorescence intensity was measured at $206 \mathrm{Ex} / \mathrm{EM}=540 / 570 \mathrm{~nm}$ in a Varioskan Lux Multimode Reader (Thermo Fisher Scientific).

207 Animals.

208 Six- to eight-week old Balb/c female mice were purchased from Harlan Mexico S.A. de 209 C.V. (Mexico, D.F.). They were kept in a pathogen- and stress-free environment at $24^{\circ} \mathrm{C}$, under a 210 light-dark cycle (light phase, 06:00-18:00 h) in a One Cage 2100 ${ }^{\text {TM }}$ System (Lab Products, Inc.,

211 Seaford, DE), and given water and food ad libitum. Animals were euthanized by asphyxiation in 212 a $100 \% \mathrm{CO}_{2}$ chamber. Experiments involving the use of animals were reviewed and approved by 213 our institutional animal care and use committee before being initiated, and were performed in 214 accordance with the Guiding Principles in the Use of Animals in Toxicology, adopted by the 215 Society of Toxicology in March 1999.

\section{Murine thymus lymphocyte viability assay.}

217 Thymus was immediately removed after mouse death. Single-cell suspensions were 218 prepared by disrupting the organ in RPMI 1640 medium. Cell suspensions were washed three 219 times in this medium, and suspended and adjusted at $1 \times 10^{7}$ cells $/ \mathrm{ml}$ in complete RPMI medium. 220 Thymus lymphocyte viability was determined by a colorimetric technique using MTT (Gomez221 Flores et al. 2009). Thymus suspensions (100 $\mu \mathrm{g}$ of $1 \times 10^{7}$ cells $\left./ \mathrm{mL}\right)$ were added to flat- 
222 bottomed 96-well plates (Becton Dickinson) containing triplicate cultures (100 $\mu \mathrm{g} / \mathrm{well})$ of 223 complete RPMI medium (unstimulated control), or $100 \mu \mathrm{L}$ of C. sorokiniana and Scenedesmus

224 sp. methanol extracts at various concentrations, for $48 \mathrm{~h}$ at $37^{\circ} \mathrm{C}$ in $95 \%$ air- $5 \% \mathrm{CO}_{2}$ atmosphere.

225 After incubation for $44 \mathrm{~h}, \mathrm{MTT}(0.5 \mathrm{mg} / \mathrm{ml}$ final concentration) was added, and cultures were

226 additionally incubated for $4 \mathrm{~h}$. Cell cultures were then incubated for $16 \mathrm{~h}$ with extraction buffer

227 (100 $\mu \mathrm{L} /$ well), and optical densities, resulting from dissolved formazan crystals, were then read 228 in a microplate reader (Becton Dickinson) at $570 \mathrm{~nm}$ (Gomez-Flores et al. 2009).

229 All experiments were repeated at least three times with similar results. The results were 230 expressed as means \pm SEM of triplicate determinations from a representative experiment.

231 Statistical significance was assessed by one-way analysis of variance and by the Student's $t$ test.

\section{RESULTS}

Microscopic evaluation revealed the presence of $C$. sorokiniana and Scenedesmus sp.

234 (Table 1), whose isolated colony cultures were then produced under axenic conditions. Culture of both microalgae in photobioreactor tanks showed that the exponential growth phase started after $12 \mathrm{~d}$ by C. sorokiniana, whereas for Scenedesmus sp., that started after $19 \mathrm{~d}$ (Fig. 1). Once the biomass was dried, collected, and weighed separately for each bioreactor, the yield by $C$. sorokiniana was of $0.24 \mathrm{~g} / \mathrm{L}( \pm 0.01)$, whereas for Scenedesmus sp. was of $0.30( \pm 0.01) \mathrm{g} / \mathrm{L}$. Microalgae methanol extracts tested in vitro against tumor cell resulted in concentrationdependent activity against the murine tumor cell line L5178Y-R. C. sorokiniana extract caused

241 significant $(p<0.05) 17 \%$ and $61 \%$ tumor cell toxicity at concentrations of 250 and $500 \mu \mathrm{g} / \mathrm{mL}$,

242 respectively, whereas that of Scenedesmus sp. induced $15 \%, 25 \%$, and $75 \%$ cytotoxicity at 243 concentrations of 125, 250, and $500 \mu \mathrm{g} / \mathrm{mL}$, respectively (Fig. 2). Collected data were used to 244 determine the inhibitory concentration mean $\left(\mathrm{IC}_{50}\right)$ of $C$. sorokiniana and Scenedesmus sp., 
245 methanolic extracts. The observed $\mathrm{IC}_{50}$ for $C$. sorokiniana, Scenedesmus sp., and vincristine were

$246460.0 \pm 21.5,362.9 \pm 13.5$, and $76.83 \pm 2.55 \mu \mathrm{g} / \mathrm{mL}$, respectively.

247 C. sorokiniana and Scenedesmus sp. methanol extracts were shown to cause DNA

248 fragmentation in L5178Y-R cells, with the typical latter pattern, after $24 \mathrm{~h}$ of treatment, which

249 was comparable with the results obtained with actinomycin D (Fig. 3A). Caspase activity assay

250 showed that Scenedesmus sp. resulted in significantly higher $(P<0.05)$ apoptosis compared with

251 the control (Fig. 3B). The AOPI staining analysis revealed that C. sorokiniana extract resulted in

$25274.4 \%$ tumor cell toxicity, 66\% apoptosis, and 9\% necrosis, whereas Scenedesmus sp. extract

253 caused 54\% tumor cell toxicity, 51\% apoptosis, and 3\% necrosis (Fig. 3C and 3D).

254 Cytotoxicity of C. sorokiniana and Scenedesmus sp. methanol extracts did not

255 significantly alter normal murine thymus lymphocyte viability, resulting in up to $26 \%$ and $19 \%$

256 not significant lymphocyte toxicity (Fig. 4).

\section{DISCUSSION}

To our knowledge, this is the first report of Nuevo Leon, Mexico native microalgae,

identified as $C$. sorokiniana and Scenedesmus sp., showing cytotoxicity against a murine

lymphoma tumor cell line. Previous reports have shown microalgae potential for wastewater

treatment and biodiesel production (Reyna-Martínez et al. 2014, Beltrán-Rocha et al. 2017). In

the present study, microalga isolates were grown under artificial light, closed photobioreactors, and previously established physicochemical conditions. Biomass production was monitored every $2 \mathrm{~d}$ by taking a $10 \mathrm{~mL}$ sample, filtered, dried, and weighed during the fermentation timecourse. Biomass calculated from time-course data indicated that Scenedesmus sp. resulted in higher (twice as much) biomass production compared with that produced by $C$. sorokiniana, 267 since values were higher than 0.8 and up to 0.4 , respectively (Fig. 1). Nonetheless, after 
268 collecting the final biomass produced by each microalgae, Scenedesmus sp. resulted in only $18 \%$

269 more biomass, compared with $C$. sorokiniana, for a total of $13.74 \mathrm{~g}$ and $11.21 \mathrm{~g}$ dried biomass,

270 respectively. C. sorokiniana and Scenedesmus sp. production in the photobioreactors was

271 stopped after $29 \mathrm{~d}$, because no additional biomass production was observed. Biomass production

272 was lower compared with other reports using batch culture and phototrophic conditions (Brennan

273 \& Owende 2010, Yeh et al. 2011). However, sufficient biomass was produced to obtain an

274 adequate amount methanol extract to perform biological assays.

275 In vitro tumor cell toxicity assays resulted in concentration-dependent activity against the

276 murine tumor cell line L5178Y-R (up to $61.9 \%$ and $74.8 \%$ cytotoxicity at $500 \mu \mathrm{g} / \mathrm{mL} C$.

277 sorokiniana and Scenedesmus sp. extracts, respectively). These results are comparable with other

278 reports showing about $50 \%$ in vitro cytotoxicity by microalga extracts against cervical cancer

279 (Yusof et al. 2010, Kyadari et al. 2013).

280 Apoptosis is the best known pathway for programmed cell death. Apoptosis and necrosis

281 can occur independently, sequentially or simultaneously. The type and/or the stimuli degree may

282 determine if cells die by apoptosis or necrosis. At low doses, a variety of injurious stimuli such as

283 heat, radiation, hypoxia, and cytotoxic anticancer drugs can induce apoptosis, or lead to necrosis

284 at higher doses (Elmore 2007). After cells enter the apoptotic process, their DNA degrades,

285 showing a ladder pattern of multiples of approximately 200 base pairs, which can be observed

286 when extracting the DNA and making an agarose gel electrophoresis. Apoptosis involves the

287 activation of caspases enzymes linked to the initiating stimuli. Caspase-3 is required for

288 apoptosis-associated chromatin margination, DNA fragmentation, and nuclear collapse of the cell

289 (Mantena, Sharma \& Katiyar 2006). After testing C. sorokiniana and Scenedesmus sp.

290 methanolic extracts, using the caspase-3/7 microplate assay, results demonstrated that only the

291 Scenedesmus sp. methanolic extract was significantly different compared with the untreated cells 
292 (negative control), whereas no differences were observed with either actinomycin D or $C$.

293 sorokiniana methanolic extract. Microalgae-induced tumor cytotoxicity was observed to be

294 mediated by apoptosis, as determined by the acridine orange and ethidium bromide staining, as

295 well as DNA fragmentation (ladder pattern) (Nagata 2000). In fact, microalga isolates methanol

296 extracts resulted in similar effects against the cell line compared with actinomycin D, compound

297 that resulted in cellular apoptosis (Quintanilla-Licea et al. 2012). After testing crude extracts of

298 the cyanobacteria Nostoc sp., against human pancreatic tumor cells PaTu 8902, Voráčová et al.

299 (2017) found that apoptosis was mostly mediated by caspases 3 and 7. In summary, DNA

300 fragmentation, acridine orange/ ethidium bromide staining, and caspases results support apoptosis

301 as the cell-death mechanism by the tested microalgae methanolic extracts (Towhid et al. 2013).

302 Tumor cancer cells may develop as a result of in situ formation of nitrosamines from

303 secondary amines and nitrite in an acidic environment of the stomach. There are chemical agents

304 known as chemopreventers, which help to reverse, suppress or prevent these nitrosamines

305 formation. In fact, ascorbic acid or phenolic compounds are chemopreventers, since they prevent

306 or reduced nitrosamines formation (Jahan et al. 2017). It has been shown that microalgae

307 synthesize a number of bioactive compounds, including bioactive peptides, fucans, galactans,

308 alginates, phenolic compounds, phycocyanins, phycobiliproteins, eicosapentanoic and

309 arachidonic acids, carotenoids, tocopherols, sterols, and terpenoids (Lordan, Ross \& Stanton

310 2011). Some of these compounds may be responsible for the cytotoxicity induced by $C$.

311 sorokiniana and Scenedesmus sp. methanol extracts, against the murine lymphoma cell line

312 L5178Y-R.

313 In a recent report, C. sorokiniana water extracts were evaluated against two human non-

314 small cell lung cancer (A549 and CL1-5 human lung adenocarcinoma cells) cell lines using a

315 subcutaneous xenograft tumor model. Results demonstrated the tumors growth inhibition after

316 extract oral intake in vivo, through mitochondrial-mediated apoptosis (Lin et al. 2017). 
321 2013).

323 isolated pure compounds will be performed.

\section{CONCLUSION}

The native microalgae $C$. sorokiniana and Scenedesmus sp. isolates from Nuevo Leon,

Mexico water bodies were produced under a semi-pilot level using closed photobioreactors, with affecting normal murine lymphocytes.

\section{Acknowledgements}

To Alonso A. Orozco-Flores and Enriqueta Monreal-Cuevas for technical assistance.

\section{REFERENCES}

Baudelet PH, Gagez AL, Bérard JB, Juin C, Bridiau N, Kaas R, Thiéry V, Cadoret JP, Picot L, lung cancer cells. Marine Drugs 11: 4390-4406, DOI 10.3390/md11114390. 
336 Beltrán-Rocha JC, Barceló-Quintal ID, García-Martínez M, Osornio-Berthet L, Saavedra-

Villarreal N, Villarreal-Chiu J, López-Chuken UJ, 2017. Polishing of municipal secondary effluent using native microalgae consortia. Water Science and Technology 75: 1693-1701 DOI 10.2166/wst.2017.046.

Brennan L, Owende P, 2010. Biofuels from microalgae-A review of technologies for production processing, and extractions of biofuels and co-products. Renewable \& Sustainable Energy Reviews Journal 14: 557-577 DOI 10.1016/j.rser.2009.10.009.

Cantú-Bernal SH, 2017. Estudio de la vida de anaquel de probióticos en presencia de la microalga Chlorella sp. en flan. MSci. Thesis dissertation. Universidad Autónoma de Nuevo León, Facultad de Ciencias Biológicas. México.

Chen CY, Yeh KL, Aisyah R, Lee DJ, Chang JS, 2011. Cultivation, photobioreactor design and harvesting of microalgae for biodiesel production: A critical review. Bioresource Technology 102: 71-81 DOI 10.1016/j.biortech.2010.06.159.

Coligan JE, Kruisbeek AM, Margulies DH, Shevach EM, Strober W, 1995. Related isolation procedures and functional assays. In: Current Protocols in Immunology. Ed: Coico R. John Wiley \& Sons, Inc., 1: 3.17.1 ISBN: 978-0-471-52276-8.

El Baky HHA, El-Baroty GS, Ibrahim EA, 2014. Antiproliferation and antioxidant properties of lipid extracts of the microalgae Scenedesmus obliquus grown under stress conditions. Der PharmaChemica 6: 24-34.

Elmore S, 2007. Apoptosis: a review of programmed cell death. Toxicologic Pathology 35: 495516 DOI 10.1080/01926230701320337

Gomez-Flores R, Verastegui-Rodriguez L, Quintanilla-Licea R, Tamez-Guerra P, MonrealCuevas E, Tamez-Guerra R, Rodriguez-Padilla C, 2009. Antitumor properties of Gymnosperma glutinosum leaf extracts. Cancer Investigation 27: 149-155 DOI 10.1080/07357900802192190. 
361 Jahan A, Ahmad IZ, Fatima N, Ansari VA, Akhtar J, 2017. Algal bioactive compounds in the 362 cosmeceutical industry: a review. Phycologia 56: 410-422 https://doi.org/10.2216/15.58.1

363 Kyadari M, Fatma T, Azad R, Velpandian T, 2013. Evaluation of antiangiogenic and

364 antiproliferative potential of the organic extract of green algae Chlorella pyrenoidosa.

365 Indian Journal of Pharmacology 45: 569-574 DOI 10.4103/0253-7613.121366.

366 Lee HJ, Hur SB, 2009. Genetic relationships among multiple strains of the genus Tetraselmis

367 based on partial 18S rDNA sequences. Algae 24: 205-212 DOI

$368 \quad$ 10.4490/ALGAE.2009.24.4.205.

369 Lin PY, Tsai CT, Chuang WL, Chao YH, Pan IH, Chen YK, Lin CC, Wang BY, 2017. Chlorella 370 sorokiniana induces mitochondrial-mediated apoptosis in human non-small cell lung cancer

Lordan S, Ross P, Stanton C, 2011. Marine bioactives as functional food ingredients: potential to reduce the incidence of chronic diseases. Marine Drugs 9: 1056-1100 DOI

Nagata S, 2000. Apoptotic DNA fragmentation. Experimental Cell Research 256: 12-18 DOI

López-Chuken U, Young S, Guzman-Mar L, 2010. Evaluating a 'biotic ligand model' applied to chloride-enhanced $\mathrm{Cd}$ uptake by Brassica juncea from nutrient solution at constant $\mathrm{Cd}^{2+}$ activity. Environmental Technology 31: 307-318 DOI 10.1080/09593330903470685

Mantena SK, Sharma SD, Katiyar, SK, 2006. Berberine, a natural product, induces G1-phase cell cycle arrest and caspase-3-dependent apoptosis in human prostate carcinoma cells. Molecular Cancer Therapeutics 5: 296-308 DOI 10.1158/1535-7163.MCT-05-0448

Orozco-Flores AA, Valadez-Lira JA, Oppert B, Gomez-Flores R, Tamez-Guerra R, Rodriguez- 
thuringiensis susceptibility and hemolin expression in Plodia interpunctella. Journal of Insect Physiology 98: 275-283 DOI 10.1016/j.jinsphys.2017.01.020

388

389

390

391

392

393

Quintanilla-Licea R, Morado-Castillo R, Gomez-Flores R, Laatsch H, Verde-Star J, HernandezMartinez H, Tamez-Guerra P, Tamez-Guerra R, Rodriguez-Padilla C, 2012. Bioassayguided isolation and identification of cytotoxic compounds from Gymnosperma glutinosum leaves. Molecules 17: 11229-11241 DOI 10.3390/molecules170911229.

Rengarajan T, Rajendran P, Nandakumar N, Balasubramanian MP, Nishigaki I, 2013. Cancer preventive efficacy of marine carotenoid fucoxanthin: cell cycle arrest and apoptosis. Nutrients 5: 4978-4989 DOI 10.3390/nu5124978

Reyna-Martínez R, Gomez-Flores R, López-Chuken U, González-González R, FernándezDelgadillo S, Balderas-Rentería I, 2014. Lipid production by pure and mixed cultures of Chlorella pyrenoidosa and Rhodotorula mucilaginosa isolated in Nuevo Leon, Mexico. Applied Biochemistry and Biotechnology 175: 354-359 DOI 10.1007/s12010-014-1275-6.

Shalaby E, 2011. Algae as promising organisms for environment and health. Plant Signaling and Behavior. 9: 1338-1350. DOI 10.4161/psb.6.9.16779.

Shanab SM, Mostafa SS, Shalaby EA, Mahmoud GI, 2012. Aqueous extracts of microalgae exhibit antioxidant and anticancer activities. Asian Pacific Journal of Tropical Medicine 2: 608-615 DOI 10.1016/S2221-1691(12)60106-3.

Teas J, Irhimeh R, 2012. Dietary algae and HIV/AIDS: proof of concept clinical data. Journal of Applied Phycology 24: 575-582 DOI 10.1007/s10811-011-9766-0.

Towhid ST, Liu GL, Ackermann TF, Beier N, Scholz W, Fuchß T, Lang F, 2013. Inhibition of colonic tumor growth by the selective SGK inhibitor EMD638683. Cellular Physiology and Biochemistry, 32: 838-848 DOI 10.1159/000354486.

Voráčová K, Paichlová J, Vicková K, Hrouzek P, 2017. Screening of cyanobacterial extracts for apoptotic inducers: a combined approach of caspase-3/7 homogeneous assay and time-lapse 
411 microscopy. Journal of Applied Phycology 29: 1933-1943 DOI 10.1007/s10811-017-11224126.

413 Yusof Y, Saad S, Makpol S, Shaaman N, Ngah W, 2010. Hot water extract of Chlorella vulgaris 414 induced DNA damage and apoptosis. Clinics 65: 1371-1377 DOI 10.1590/S1807$415 \quad 59322010001200023$. 
417 Fig. 1. Biomass production time-course by Chlorella sorokiniana and Scenedesmus sp. isolates. Data represent means \pm SEM.

Fig. 2. L5178Y-R tumor cell toxicity of Chlorella sorokiniana and Scenedesmus sp. methanol extracts. Microalgae methanol extracts were tested against L5178Y-R cells in vitro at concentrations ranging from 7.8 to $500 \mu \mathrm{g} / \mathrm{mL}$, as detailed in the text. Positive control vincristine caused $85 \% \pm 1.22$ cytotoxicity at $250 \mu \mathrm{g} / \mathrm{mL}$. Data represent means $\pm \mathrm{SEM}$. $* P<0.05 ; * * P<0.01$.

Fig. 3. Apoptosis of L5178Y-R tumor cells. (A) Agarose gel showing the cellular DNA fragmentation by line L5178Y-R after treatment with microalgae methanolic extracts. Lane 1, 100 bp molecular weight marker; lanes 2 and 3, cellular DNA after treatment with Chlorella sorokiniana methanolic extracts at 500 and $250 \mu \mathrm{g} / \mathrm{mL}$, respectively; 4 and 5 cellular DNA after treatment with Scenedesmus sp. methanolic extracts at 500 and 250 $\mu \mathrm{g} / \mathrm{mL}$, respectively; lane 6, cellular DNA treated with actinomycin D at $20 \mu \mathrm{g} / \mathrm{mL}$. (B) Detection of caspase 3/7 enzymes activity in L5178Y-R cells (CaspGLOW ${ }^{\mathrm{TM}}$ ), testing 500,000 cells per well on the same day, untreated or treated with Actinomycin D (800 $\mathrm{ng} / \mathrm{mL}$ ) as positive control, and C. sorokiniana or Scenedesmus sp. methanol extracts at $500 \mu \mathrm{g} / \mathrm{mL}$, incubated by $24 \mathrm{~h}$ at $37^{\circ} \mathrm{C}$ and reading fluorescence intensity at $\mathrm{Ex} / \mathrm{EM}=$ 540/570 nm. (C) Effects of C. sorokiniana and Scenedesmus sp. methanol extracts on percent viable, apoptotic, and necrotic cells. Percentage of viable, apoptotic, and necrotic L5178Y-R cells after $24 \mathrm{~h}$ treatment with $500 \mu \mathrm{g} / \mathrm{mL}$ C. sorokiniana and Scenedesmus $\mathrm{sp}$. methanol extracts, and actinomycin D (20 $\mu \mathrm{g} / \mathrm{mL})$. (D) L5178Y-R cells stained with acridine orange/ethidium bromide used to discriminate viable, apoptotic and necrotic cells after C. sorokiniana and Scenedesmus sp. methanol extracts treatment. 
440 Fig. 4. Effects of Chlorella sorokiniana and Scenedesmus sp. methanol extracts on viability of

441 normal murine thymus lymphocytes. Thymus lymphocyte viability was determined by a

colorimetric technique using MTT (Gomez-Flores et al. 2009). Thymus suspensions were incubated with culture medium alone or with C. sorokiniana and Scenedesmus sp. methanol extracts at various concentrations, for $48 \mathrm{~h}$ at $37^{\circ} \mathrm{C}$, and cell viability was determined as detailed in the text. 


\section{Table 1 (on next page)}

Locations from Nuevo Leon state, Mexico, where microalgae were isolated. 
Table 1. Locations from Nuevo Leon state, Mexico, where microalgae were isolated

Location

Microalga

Microscopic

shape $(100 x)$

San Juan River, Cadereyta, N.L.

$25^{\circ} 31^{\prime} 17^{\prime \prime}-100^{\circ} 0^{\prime} 34^{\prime \prime}$

Pesquería River, Apodaca, N.L.

$25^{\circ} 46^{\prime} 34^{\prime \prime}-100^{\circ} 12^{\prime} 35^{\prime \prime}$
Chlorella sorokiniana

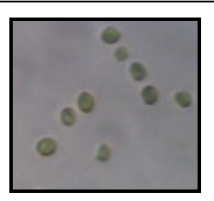

Scenedesmus sp.

1 
Figure 1

Biomass production time-course by Chlorella sorokiniana and Scenedesmus sp. isolates.

Data represent means \pm SEM.

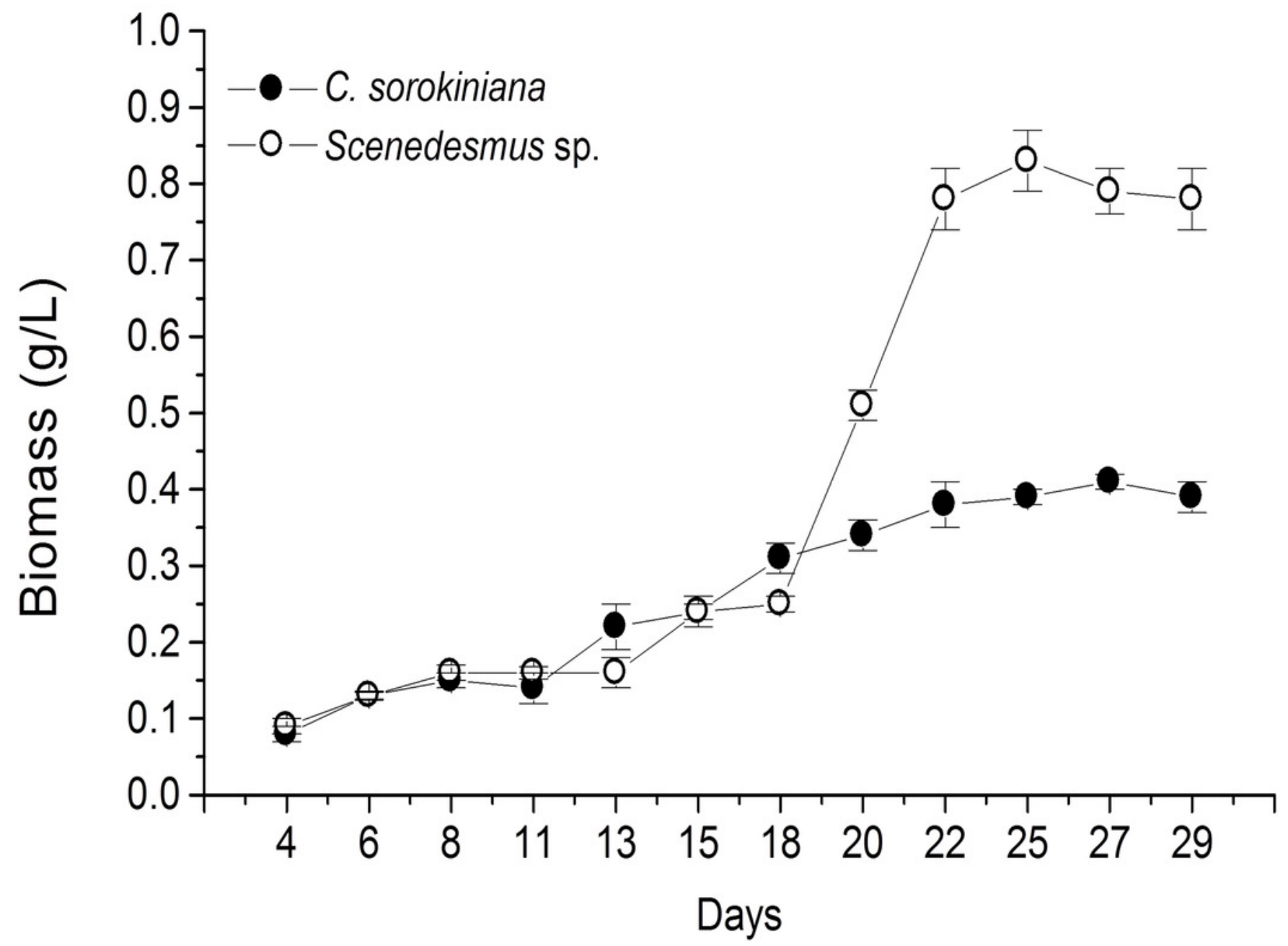


Figure 2

L5178Y-R tumor cell toxicity of Chlorella sorokiniana and Scenedesmus sp. methanol extracts.

Microalgae methanol extracts at concentrations ranging from 7.8 to $500 \mu \mathrm{g} / \mathrm{mL}$ were tested against L5178Y-R cells in vitro, as detailed in the text. Positive control vincristine caused $85 \%$ \pm 1.22 cytotoxicity at $250 \mu \mathrm{g} / \mathrm{mL}$. Data represent means \pm SEM. $* P<0.05 ; * * P<0.01$.

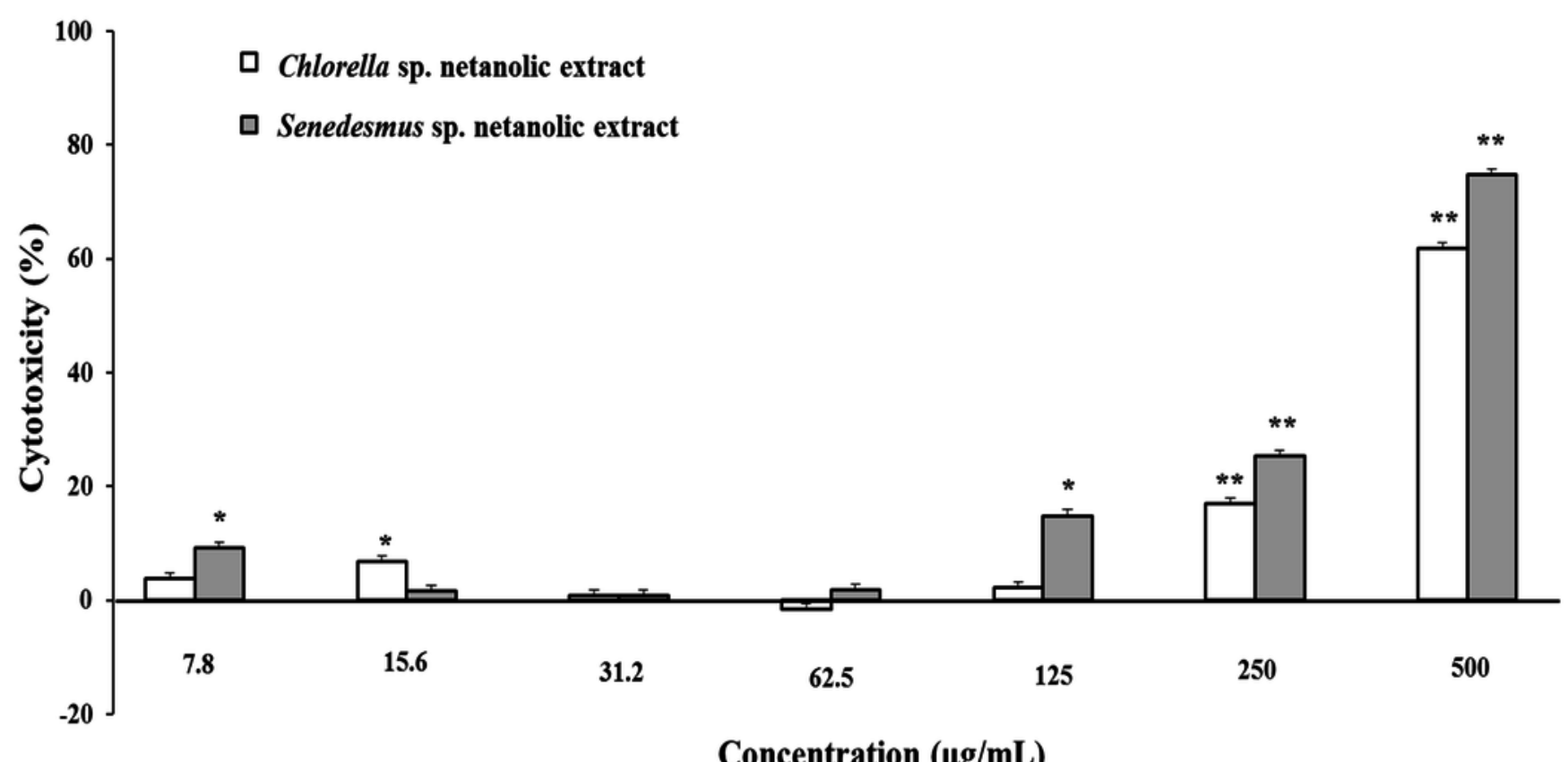




\section{Figure 3}

Apoptosis of L5178Y-R tumor cells.

(A) Agarose gel showing the cellular DNA fragmentation by line L5178Y-R after treatment with microalgae methanolic extracts. Lane 1, 100 bp molecular weight marker; lanes 2 and 3, cellular DNA after treatment with Chlorella sorokiniana methanolic extracts at 500 and 250 $\mu \mathrm{g} / \mathrm{mL}$, respectively; 4 and 5 cellular DNA after treatment with Scenedesmus sp. methanolic extracts at 500 and $250 \mu \mathrm{g} / \mathrm{mL}$, respectively; lane 6, cellular DNA treated with actinomycin D at $20 \mu \mathrm{g} / \mathrm{mL}$. (B) Detection of caspase 3/7 enzymes activity in L5178Y-R cells (CaspGLOW ${ }^{\mathrm{TM}}$ ), testing 500,000 cells per well on the same day, untreated or treated with Actinomycin D (800 $\mathrm{ng} / \mathrm{mL}$ ) as positive control, and C. sorokiniana or Scenedesmus sp. methanol extracts at 500 $\mu \mathrm{g} / \mathrm{mL}$, incubated by $24 \mathrm{~h}$ at $37^{\circ} \mathrm{C}$ and reading fluorescence intensity at $\mathrm{Ex} / \mathrm{EM}=540 / 570$ $\mathrm{nm}$. (C) Effects of $C$. sorokiniana and Scenedesmus sp. methanol extracts on percent viable, apoptotic, and necrotic cells. Percentage of viable, apoptotic, and necrotic L5178Y-R cells after $24 \mathrm{~h}$ treatment with $500 \mu \mathrm{g} / \mathrm{mL}$ C. sorokiniana and Scenedesmus sp. methanol extracts, and actinomycin D (20 $\mathrm{gg} / \mathrm{mL})$. (D) L5178Y-R cells stained with acridineorange/ethidiumbromide used to discriminate viable, apoptotic and necrotic cells after $C$. sorokiniana and Scenedesmus sp. methanol extracts treatment. 

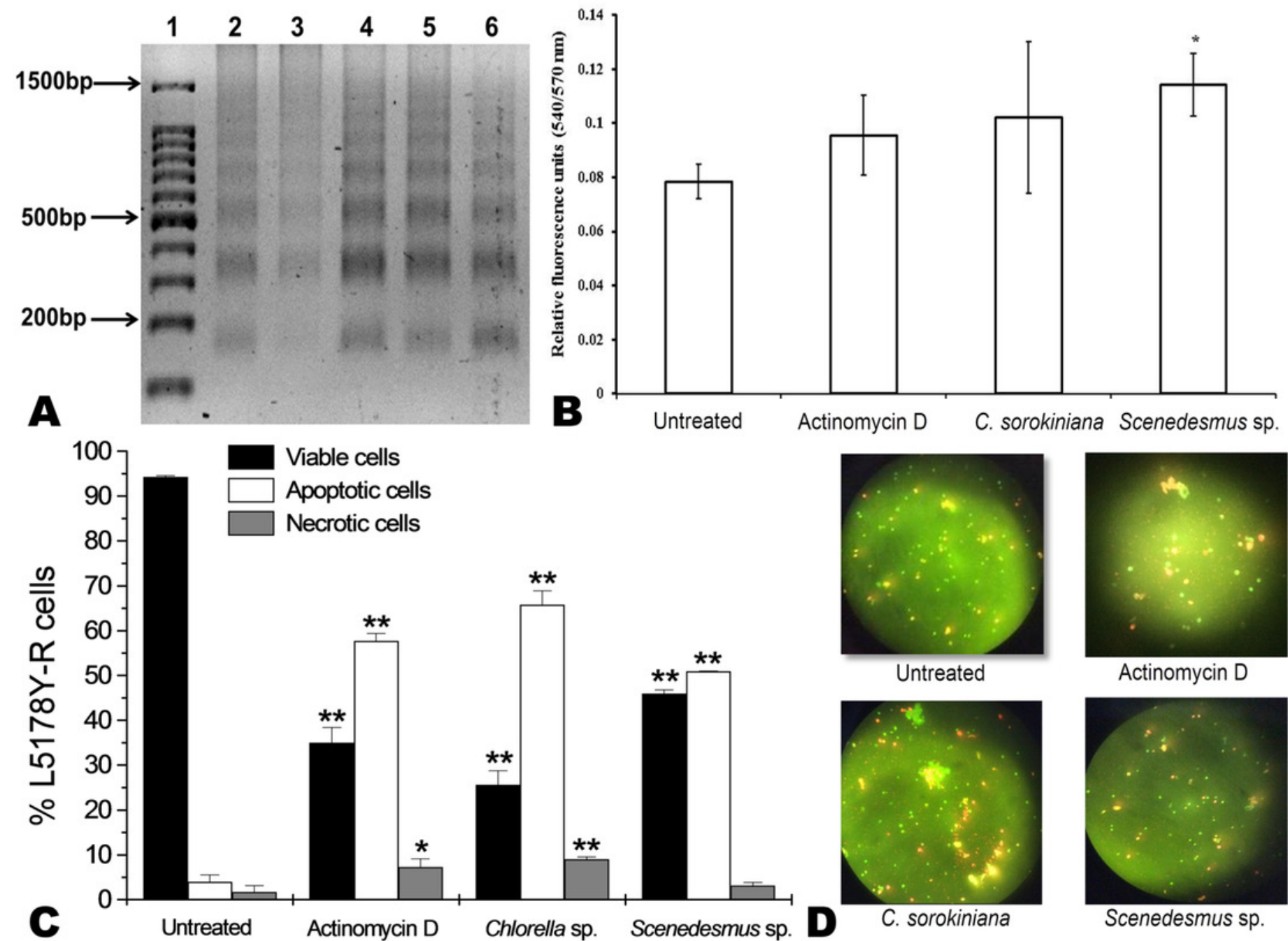

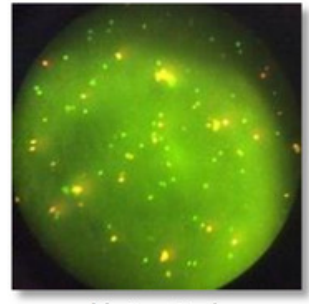

Untreated

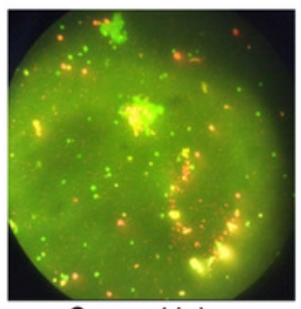

C. sorokiniana

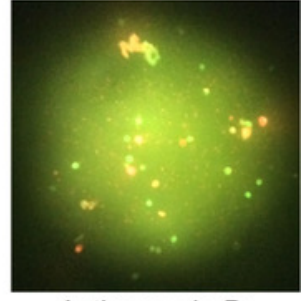

Actinomycin D

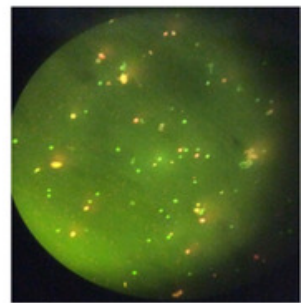

Scenedesmus sp. 


\section{Figure 4}

Thymus lymphocyte viability

Effects of Chlorella sorokiniana and Scenedesmus sp. methanol extracts on viability of normal murine thymus lymphocytes. Thymus lymphocyte viability was determined by a colorimetric technique using MTT (Gomez-Flores et al. 2009). Thymus suspensions were incubated with culture medium alone or with C. sorokiniana and Scenedesmus sp. methanol extracts at various concentrations, for $48 \mathrm{~h}$ at $37^{\circ} \mathrm{C}$, and cell viability was determined as detailed in the text.

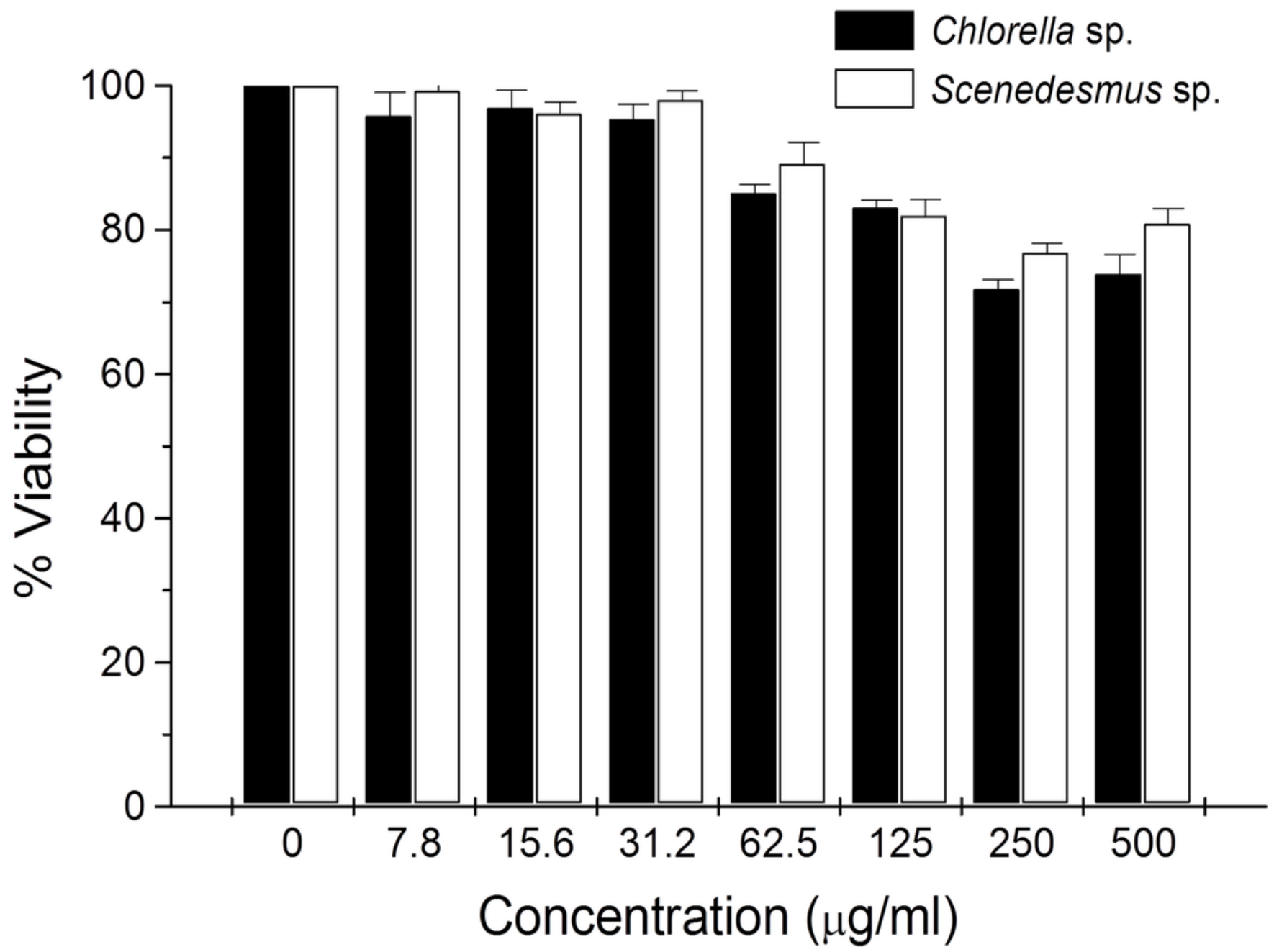

